\title{
Effect of potassium deficiency on antioxidant status and cadmium toxicity in rice seedlings
}

\author{
Chun-Hsin Liu, Yun-Yang Chao and Ching Huei Kao*
}

\begin{abstract}
Background: Cadmium (Cd) is one of the most toxic heavy metals and inhibits physiological processes of plants. Potassium (K) is an essential macronutrient in plants. $\mathrm{K}$ deficiency and $\mathrm{Cd}$ stress represent two different abiotic stress conditions that occur in the field simultaneously. In this study, effects of $K$ deficiency on antioxidant status and $\mathrm{Cd}$ toxicity in rice seedlings were investigated.

Results: $\mathrm{K}$ deficiency significantly decreased $\mathrm{K}$ concentration in shoots and roots. However, fresh weight and dry weight of rice seedlings were not affected by $\mathrm{K}$ deficiency. The activities of antioxidant enzymes (superoxide dismutase, ascorbate peroxidase, glutathione reductase, and catalase) in K-deficient leaves were higher than respective control leaves. However, K deficiency had no effect on the content of antioxidants (ascorbate and glutathione). Cd toxicity was judged by the decrease in biomass production, chlorosis, and induction of oxidative stress. Based on these criteria, we demonstrated that $\mathrm{K}$ deficiency protected rice seedling from $\mathrm{Cd}$ stress. Moreover, chlorophyll concentration was higher in K-deficient shoots and roots than their respective control shoots and roots.

Conclusions: Our results indicated that $\mathrm{K}$ deficiency protects rice seedlings from Cd toxicity. This protective effect of $\mathrm{K}$ deficiency is mainly due to enhanced antioxidant enzyme activities but not inhibition of $\mathrm{Cd}$ uptake.
\end{abstract}

Keywords: Antioxidant system; Cadmium; Potassium deficiency; Rice

\section{Background}

Cadmium is a widespread metal contaminating many areas, either naturally or because of industrial use (Pan et al., 2010). Because of its long biological half-life, $\mathrm{Cd}$ is highly toxic. In plants, $\mathrm{Cd}$ is easily taken up by roots and translocated into shoots. Once Cd is taken up by plants, many cellular structures and metabolic processes are affected (Sanitá di Toppi and Gabbrielli, 1999; Gratăo et al., 2005). Cd is a bivalent cation and unable to generate free radicals directly, nevertheless the production of reactive oxygen species (ROS) after $\mathrm{Cd}$ exposure has been reported (Sanitá di Toppi and Gabbrielli, 1999; Gratăo et al., 2005; Cuypers et al., 2010). ROS has to be kept under tight control because their accumulation results in cell death due to oxidative processes such as lipid peroxidation, protein oxidation, and DNA damage (Gill and Tuteja, 2010). Plants use antioxidant enzymes such as superoxide dismutase (SOD), ascorbate peroxidase (APX), glutathione reductase (GR), and

\footnotetext{
* Correspondence: kaoch@ntu.edu.tw

Department of Agronomy, National Taiwan University, Taipei, Taiwan, ROC
}

catalase (CAT) as well as non-enzymatic antioxidants such as ascorbate (AsA) and glutathione (GSH) to scavenge ROS (Noctor and Foyer 1998; Amudha and Balasubnramani 2011; Foyer and Noctor, 2011).

In agricultural systems, high-density monoculture crops deplete soil minerals quickly and therefore rely on external supplies for most of their nutrients, particularly nitrogen, potassium (K) and phosphorus (Amtmann et al., 2006). A balanced supply of mineral nutrients is crucial for both quantity and quality of the crop, but rarely achieved in the field. Of the mineral nutrients, imbalanced nutrition with $\mathrm{K}$ is well known and becoming an important constraint to crop production in many areas (Cakmak, 2010).

Potassium (K) is an essential macronutrient and plays an important role in metabolism as it functions as a cofactor of many enzymes and is required for charge balance and transport of metabolites (Marschner, 1995). It has been shown that the rate of net photosynthesis and the activity of ribulose-1, 5-bisphosphate carboxylase decrease in plants under conditions of $\mathrm{K}$ deficiency (Peoples and Koch 1979; Zhao et al., 2001; Cakmak, 2005; Weng et al., 2007). Several lines of evidence have also shown that $\mathrm{K}$ deficiency 
causes a decrease in sucrose export from source leaves (Mengel and Viro, 1974; Cakmak, 2005). Thus, the impairment in photosynthetic $\mathrm{CO}_{2}$ fixation and decrease in sucrose export in K-deficient leaves could lead to enhanced oxygen photoreduction in the chloroplast via the Mehler reaction resulting in the production of ROS. In order to detoxify ROS, increases in the activities/contents of antioxidants are expected in leaves of K-deficient plants. Indeed, enhancement in the activities of antioxidant enzymes has been demonstrated in K-deficient bean leaves (Cakmak, 1994, 2005). Ding et al. (2008) also reported that the activities of SOD, CAT and peroxidase in the leaves of rice plants supplied with low $\mathrm{K}(0.5 \mathrm{mM})$ were higher than those supplied with high $\mathrm{K}(6 \mathrm{mM})$.

In the field, crops and other plants are routinely subjected to a combination of different abiotic stresses. For this reason, the importance of focusing the research programs in the response of plants to a combination of two different abiotic stresses has been emphasized (Mittler, 2006). Recently, we have revealed that $\mathrm{Mg}$ deficiency protects rice seedlings from Cd stress (Chou et al., 2011). In contrast, $\mathrm{N}$ deficiency was observed to enhance subsequent toxicity in rice seedlings caused by $\mathrm{Cd}$ stress (Lin et al., 2011). K deprivation and $\mathrm{Cd}$ stress represent another example of two different abiotic stress conditions that occur in the field simultaneously. However, it is not known whether Cd stress of rice seedlings is influenced by $\mathrm{K}$ deficiency. The present study was undertaken with the objective to examine the effect of $\mathrm{K}$ deficiency on antioxidant status and subsequent Cd-induced toxicity in rice seedlings.

\section{Material and methods}

\section{Plant material and growth conditions}

Rice (Oryza sativa L., cv. Taichung Native 1) seeds were sterilized with $2.5 \%$ sodium hypochlorite for $15 \mathrm{~min}$ and washed extensively with distilled water. These seeds were then germinated in Petri dishes with wetted filter papers at $37^{\circ} \mathrm{C}$ in the dark. After $48 \mathrm{~h}$ incubation, uniformly germinated seeds were selected and cultivated in a beaker containing half-strength Kimura B nutrient solution with sufficient $\mathrm{K}$ supply (control) or deficient $\mathrm{K}$ supply $(-\mathrm{K})$. Nutrient solution for the control contains the following macro- and micro-elements: $182.3 \mu \mathrm{M}$ $\left(\mathrm{NH}_{4}\right)_{2} \mathrm{SO}_{4}, 91.6 \mu \mathrm{M} \mathrm{KNO}_{3}, 273.9 \mu \mathrm{M} \mathrm{MgSO}_{4}, 7 \mathrm{H}_{2} \mathrm{O}$, $91.1 \mu \mathrm{M} \mathrm{K} \mathrm{KH}_{2} \mathrm{PO}_{4}, 182.5 \mu \mathrm{M} \mathrm{Ca}\left(\mathrm{NO}_{3}\right)_{2}, 30.6 \mu \mathrm{M}$ Fecitrate, $0.25 \mu \mathrm{M} \mathrm{H}_{3} \mathrm{BO}_{3}, 0.2 \mu \mathrm{M} \mathrm{MnSO} \mathrm{M}_{4} \cdot \mathrm{H}_{2} \mathrm{O}, 0.2 \mu \mathrm{M}$ $\mathrm{ZnSO}_{4} \cdot 7 \mathrm{H}_{2} \mathrm{O}, 0.05 \mu \mathrm{M} \mathrm{CuSO}_{4} \cdot 5 \mathrm{H}_{2} \mathrm{O}$ and $0.07 \mu \mathrm{M}$ $\mathrm{H}_{2} \mathrm{MoO}_{4}$ (Kimura, 1931). Sodium nitrate substituted for $\mathrm{KNO}_{3}$ and $\mathrm{NaH}_{2} \mathrm{PO}_{4}$ for $\mathrm{KH}_{2} \mathrm{PO}_{4}$, respectively, under $\mathrm{K}$-deficient conditions. Kimura $\mathrm{B}$ nutrient solution contains the desired nutrients for growing rice plants. Since young rice seedlings were used for the present study, the nutrient solution contained no silicon, although silicon is essential for growth of sturdy rice plants in the field.
Nutrient solution ( $\mathrm{pH}$ 4.7) were replaced every 3 days. The hydroponically cultivated seedlings were grown in a Phytotron (Agricultural Experimental Station, National Taiwan University, Taipei, Taiwan) with natural sunlight at $30 / 25^{\circ} \mathrm{C}$ day/night and $90 \%$ relative humidity. Four beakers were used for each treatment, with 20 seedlings in each beaker. Twelve-day-old seedlings with three leaves were then grown with or without $\mathrm{CdCl}_{2}(5 \mu \mathrm{M})$ for 6 days. Cd toxicity (chlorosis, chlorophyll loss, and lipid peroxidation) was first shown in the second leaves of rice seedlings (Hsu and Kao, 2005). For this reason, unless otherwise indicated the second leaves of rice seedlings were used to perform all the chemical measurements and enzyme assays.

\section{Determination of $\mathrm{K}$ and $\mathrm{Cd}$}

For determination of $\mathrm{K}$ and $\mathrm{Cd}$, samples were dried at $65^{\circ} \mathrm{C}$ for 2 days. Dried material was ashed at $550^{\circ} \mathrm{C}$ for 4 days. The ash residue was incubated with $70 \% \mathrm{HNO}_{3}$ and $30 \% \mathrm{H}_{2} \mathrm{O}_{2}$ at $72^{\circ} \mathrm{C}$ for $2 \mathrm{~h}$, and dissolved in distilled water for detection of $\mathrm{K}$ and $\mathrm{Cd}$. $\mathrm{K}$ and $\mathrm{Cd}$ concentrations were then quantified using an atomic absorption spectrophotometer (Model AA-6800, Shimadzu, Kyoto, Japan) and expressed on a dry weight (DW) basis.

\section{Growth response}

At the end of treatment, the seedlings were divided into shoots and roots. For DW estimation, the shoots and roots were dried at $65^{\circ} \mathrm{C}$ for $48 \mathrm{~h}$, by which time the DW remains constant.

\section{Determination of $\mathrm{H}_{2} \mathrm{O}_{2}$, chlorophyll, and MDA}

The $\mathrm{H}_{2} \mathrm{O}_{2}$ was extracted with sodium phosphate buffer (50 mM, pH 6.8) containing $1 \mathrm{mM}$ hydroxylamine, a catalase inhibitor. The $\mathrm{H}_{2} \mathrm{O}_{2}$ content was measured after reaction with $\mathrm{TiCl}_{4}$ (Tsai et al., 2004). The blank reaction consisted of $50 \mathrm{mM}$ phosphate buffer in the absence of leaf extracts. The absorbance was measured at $410 \mathrm{~nm}$. The amount of $\mathrm{H}_{2} \mathrm{O}_{2}$ was calculated by using a standard curve prepared with known concentrations of $\mathrm{H}_{2} \mathrm{O}_{2}$.

The chlorophyll content was determined according to Wintermans and De Mots (1965) after extraction in 96\% $(\mathrm{v} / \mathrm{v})$ ethanol. For protein determination, leaves were homogenized in a $50 \mathrm{mM}$ sodium phosphate buffer (pH 6.8). The extracts were centrifuged at $17,600 \mathrm{~g}$ for $20 \mathrm{~min}$, and the supernatants were used for determination of protein by the method of Bradford (1976). Malondialdehyde (MDA), routinely used as an indicator of lipid peroxidation, was extracted with $5 \%(\mathrm{w} / \mathrm{v})$ trichloroacetic acid and determined by the thiobarbituric acid reaction as described by Heath and Packer (1968). The contents of $\mathrm{H}_{2} \mathrm{O}_{2}$, chlorophyll, and MDA were expressed on the basis of fresh weight (FW) of the second leaves prior to $\mathrm{Cd}$ treatment. 
Determination of AsA, dehydroascorbate (DHA), GSH, andoxidized glutathione (GSSG)

Ascorbic acid (AsA) and DHA contents in 5\% (w/v) trichloroacetic acid were determined as described by Law et al. (1983). The assay is based on the reduction of $\mathrm{Fe}^{3+}$ to $\mathrm{Fe}^{2+}$ by AsA. The $\mathrm{Fe}^{2+}$ then forms complexes with bipyridyl, giving a pink color that absorbs at $525 \mathrm{~nm}$. GSH and GSSG contents in 3\% sulfosalicylic acid extract were determined by the method of Smith (1985). The content of GSH was spectrophotometrically determined with an enzyme-recycling assay at $412 \mathrm{~nm}$. The assay is based on sequential oxidation of GSH by 5, 5-dithiobis-(2-nitrobenzoic acid) and reduction by NADPH in the presence of known amount of GR. The contents of AsA, DHA, GSH and GSSG were expressed on the basis of FW of the second leaves prior to $\mathrm{Cd}$ treatment.

\section{Enzyme extraction and assays}

Leaf samples were excised and immediately used for enzyme extraction. All operations were carried out at $4^{\circ} \mathrm{C}$. For extraction of enzymes, leaf tissues (about $70 \mathrm{mg}$ FW) were homogenized with $0.1 \mathrm{M}$ sodium phosphate buffer ( $\mathrm{pH}$ 6.8) in a chilled pestle and mortar. For analysis of APX activity, $2 \mathrm{mM}$ AsA was added to the extraction buffer. The homogenate was centrifuged at $12,000 \mathrm{~g}$. SOD activity was determined according to Paoletti et al. (1986). This method, originally used for animal material (liver), has been used to determine SOD activity in rice (Dey and Kar, 1995), maize (Bennicelli et al., 1998), cucumber (Piacentini et al., 2001), wheat (Goggin and Colmer, 2005), and potato (Agrawal et al., 2008). The reaction mixture $(2.73 \mathrm{~mL}$ ) contained $100 \mathrm{mM}$ triethanolamine-diethanolamine buffer (pH 7.4), 7.5 mM NADH, EDTA/ $\mathrm{MnCl}_{2}(100 \mathrm{mM} / 50 \mathrm{mM}$, $\mathrm{pH}$ 7.4), $10 \mathrm{mM}$ 2-mercaptoethanol, and enzyme extract $(0.2 \mathrm{~mL})$. The reaction was started by the addition of $\mathrm{NADH}$. The reaction was allowed to proceed for $10 \mathrm{~min}$. The absorbance was measured at $340 \mathrm{~nm}$. One unit of SOD was defined as the amount of enzyme that inhibited by $50 \%$ the rate of $\mathrm{NADH}$ oxidation observed in blank sample. CAT activity was assayed according to Kato and Shimizu (1987). The decrease in $\mathrm{H}_{2} \mathrm{O}_{2}$ was followed as the decline in the absorbance at $240 \mathrm{~nm}$, and the activity was calculated using the extinction coefficient $\left(40 \mathrm{mM}^{-1} \mathrm{~cm}^{-1}\right.$ at $240 \mathrm{~nm}$ ) for $\mathrm{H}_{2} \mathrm{O}_{2}$. One unit of CAT was defined as the amount of enzyme which degraded $1 \mu$ mol $\mathrm{H}_{2} \mathrm{O}_{2}$ per min. APX activity was determined according to Nakano and Asada (1981). The decrease in AsA concentration was
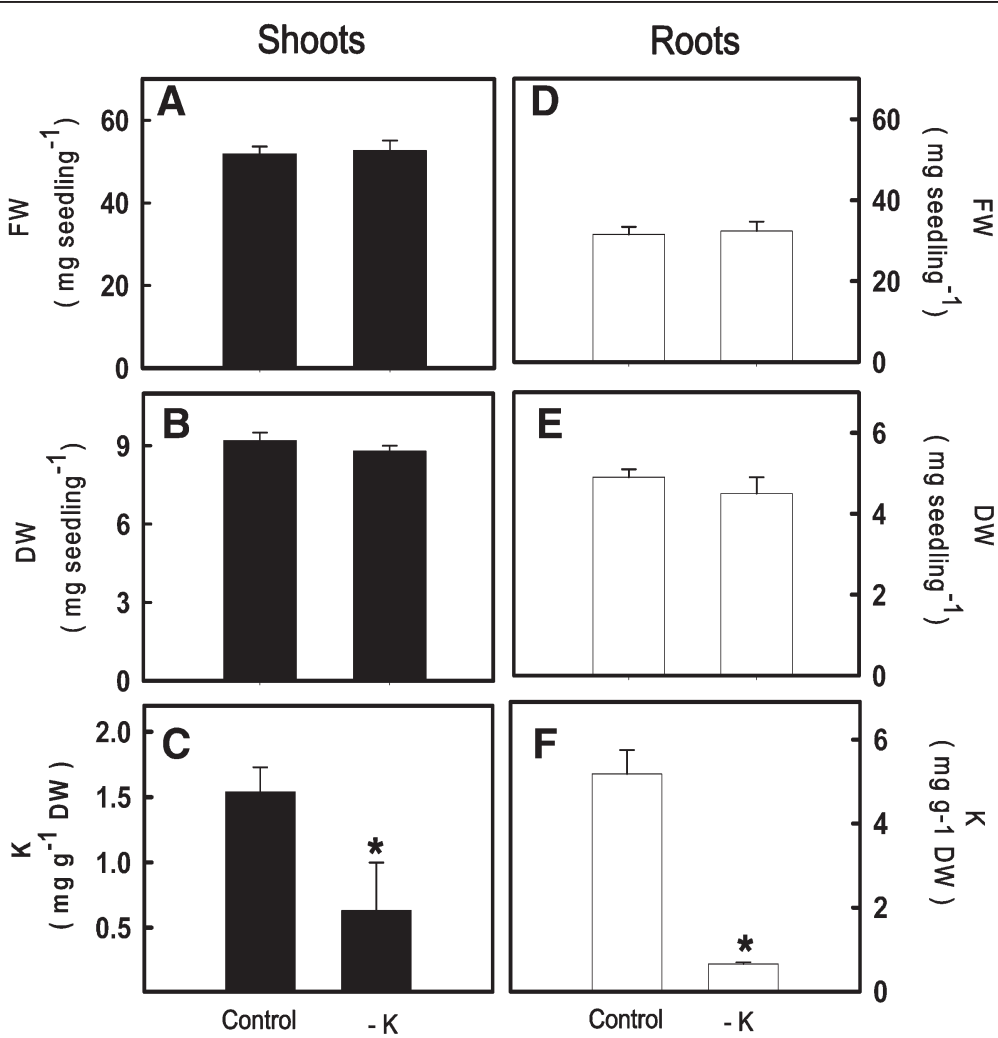

Figure 1 The fresh weight (FW) (A, D), dry weight (DW) $(B, E)$ and $K$ concentration $(C, F)$ in shoots and roots of rice seedlings. Rice seedlings were grown under K-sufficient (control) and -deficient $(-K)$ conditions for 12 days. The shoots and roots were then used to determine FW, DW, and K concentration. Bars indicate standard errors $(n=4)$. Asterisks represent values that are significantly different between control and $-\mathrm{K}$ treatments at $P<0.05$. 
followed as a decline in the absorbance at $290 \mathrm{~nm}$ and activity was calculated using the extinction coefficient $\left(2.8 \mathrm{mM}^{-1} \mathrm{~cm}^{-1}\right.$ at $\left.290 \mathrm{~nm}\right)$ for AsA. One unit of activity for APX was defined as the amount of enzyme that degraded $1 \mu \mathrm{mol}$ of AsA per min. GR was defined as the amount of enzyme of Foster and Hess (1980). One unit of GR was defined as the amount of enzyme that decreased 1 optical density $\mathrm{min}^{-1}$ at $340 \mathrm{~nm}$. Enzyme activities were expressed on the basis of $\mathrm{mg}$ protein.

\section{Paraquat resistance}

To test if the protection effect of $\mathrm{K}$ deficiency against $\mathrm{Cd}$ toxicity is due to enhanced protection against oxidative stress, the second leaves were detached from 12-day-old rice seedlings grown under $\mathrm{K}$-sufficient and -deficient nutrition solutions. Ten detached leaves were then floated on Petri dish containing $10 \mu \mathrm{M}$ paraquat (PQ) at $27^{\circ} \mathrm{C}$ for $24 \mathrm{~h}$ in the light $\left(40 \mu \mathrm{mol} \mathrm{m} \mathrm{s}^{-1}\right)$. After incubation, 10 detached leaves per treatment (four replicates) were analyzed for chlorophyll.

\section{Statistical analyses}

Data were analyzed by Student's $t$-test or Duncan's multiple range test. $P<0.05$ was considered statistically significant.

\section{Results}

\section{Effect of $\mathrm{K}$ deficiency on growth response and $\mathrm{K}$} concentration

To examine the effect of $K$ deficiency on growth response and $\mathrm{K}$ concentration, rice seedlings were grown under

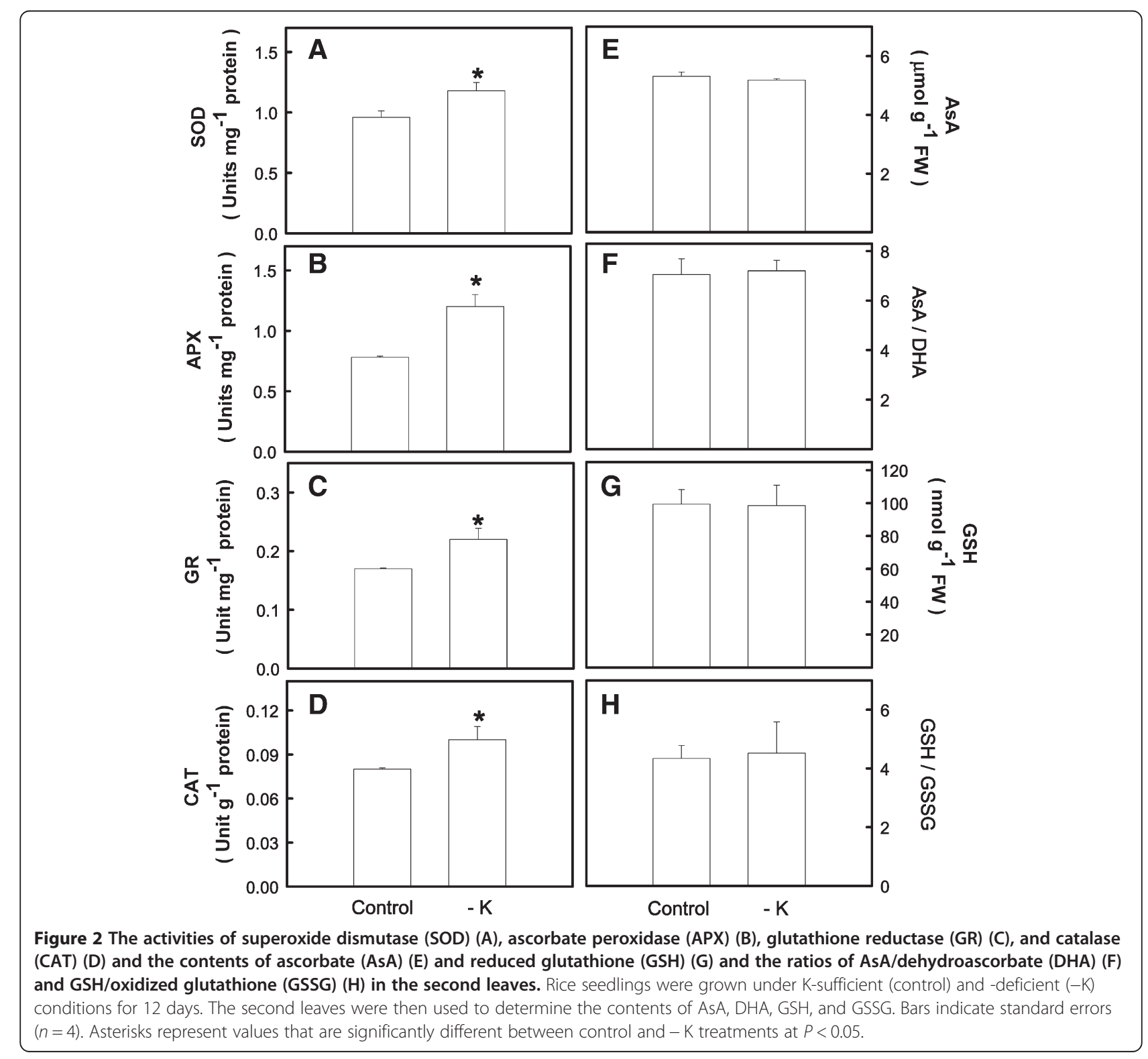


conditions of sufficient (control) and deficient $\mathrm{K}$ supply (-K) for 12 days. The FW and DW of both shoots and roots were not affected by $\mathrm{K}$ deficiency (Figure $1 \mathrm{~A}, \mathrm{~B}, \mathrm{D}$, $\mathrm{E})$. However, $\mathrm{K}$ deficiency resulted in a decrease in $\mathrm{K}$ concentration in shoots and roots (Figure 1C, F).

\section{Effect of $\mathrm{K}$ deficiency on antioxidant status}

Effects of $\mathrm{K}$ deficiency on the activities of antioxidant enzymes in the second leaves were shown in Figure 2A-D. K deficiency significantly increased the activities of SOD, APX, GR, and CAT in the second leaves. In the present study, the effect of $\mathrm{K}$ deficiency on the contents of antioxidants in the second leaves was also investigated. K deficiency had no effect on the contents of AsA and GSH and the ratios of AsA/DHA and GSH/GSSG in the second leaves (Figure 2E-H).

\section{Effect of $\mathrm{K}$ deficiency on Cd-induced changes in biomass production}

$\mathrm{Cd}$ is readily taken up by rice seedlings, leading to growth reduction (Chen and Kao, 1995). Thus, in the present study, Cd toxicity was first evaluated by biomass production (shoot and root DW). The DW of the shoots and roots in K-sufficient seedlings was significantly decreased by $\mathrm{Cd}$ (Figure 3A, B). However, Cd had no effect on the DW of the shoots and roots in $-K$ seedlings (Figure $3 \mathrm{~A}, \mathrm{~B}$ ).

\section{Effect of $\mathrm{K}$ deficiency on Cd-induced chlorosis}

In plants, the general symptom of Cd toxicity is chlorosis (Das et al., 1997). When rice seedlings were treated with $\mathrm{CdCl}_{2}$, chlorosis was first shown in the second leaves (Hsu and Kao, 2005). Thus, the second leaves were used to determine chlorosis in the present study. To test if $\mathrm{K}$ deficiency would affect $\mathrm{Cd}$ stressinduced chlorosis, 12-day-old control and K-deficient seedlings were transferred to K-sufficient and -deficient nutrient solution with or without $5 \mu \mathrm{M} \mathrm{CdCl}$ for 6 days, respectively. $\mathrm{Cd}$-induced chlorosis in $\mathrm{K}$-deficient leaves was less pronounced than their respective control leaves (Figure 4A).

\section{Effect of K deficiency on Cd-induced oxidative stress}

Previous work demonstrated that $\mathrm{Cd}$ induces oxidative stress in rice leaves, characterized by an increase in the contents of MDA (an indicator of lipid peroxidation) and $\mathrm{H}_{2} \mathrm{O}_{2}$ (Kuo and Kao, 2004; Hsu and Kao, 2007). It was observed that the increase in the contents of $\mathrm{MDA}$ and $\mathrm{H}_{2} \mathrm{O}_{2}$ caused by $5 \mu \mathrm{M} \mathrm{CdCl}_{2}$ was less pronounced in $\mathrm{K}$-deficient leaves than in control leaves (Figure 4B, C).

The striking increase in lipid peroxidation and $\mathrm{H}_{2} \mathrm{O}_{2}$ seen in K-sufficient leaves treated with $\mathrm{CdCl}_{2}$ (Figure $4 \mathrm{~B}$, C), may reflect changes in the specific activities of

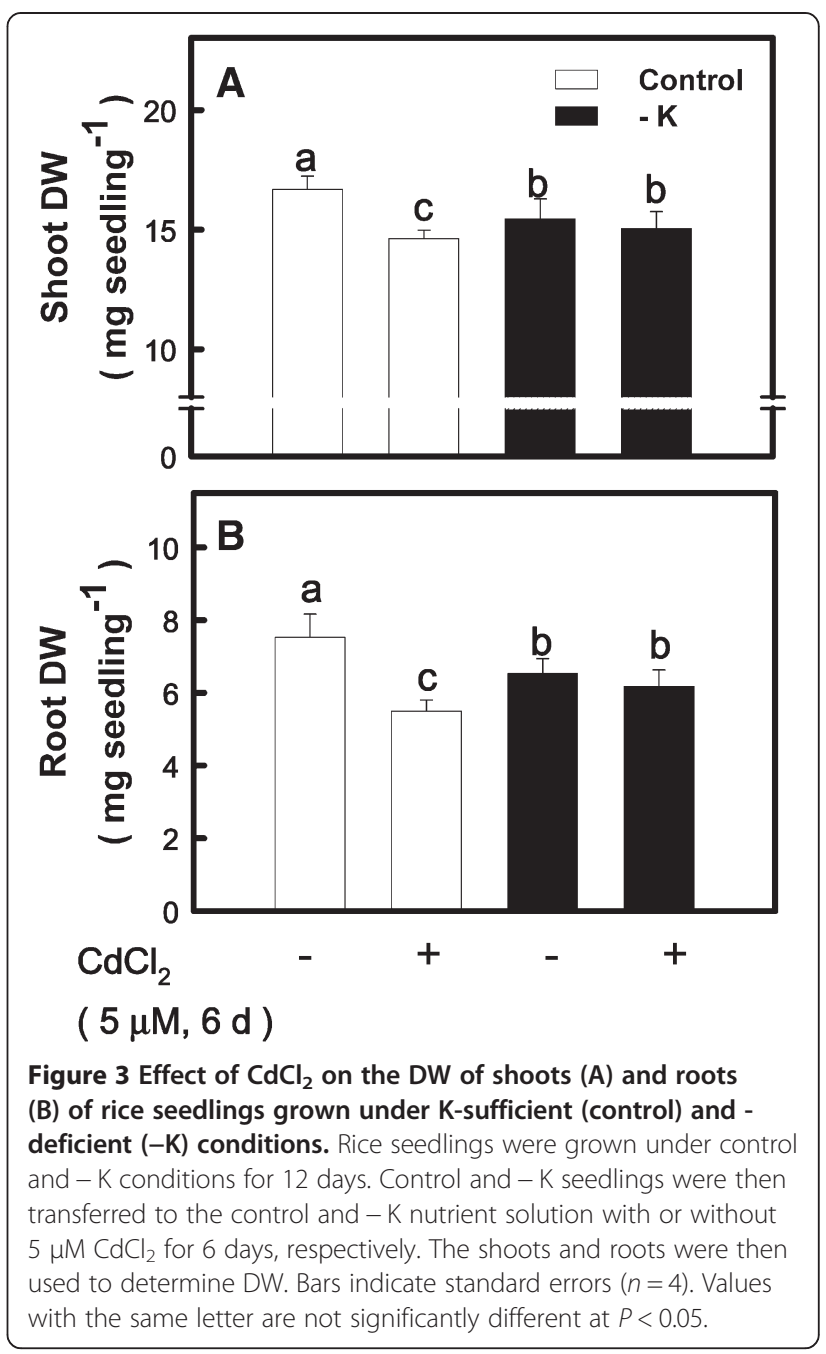

antioxidant enzymes and contents of antioxidants. Here, we showed that the increase in the activities of SOD, APX, $\mathrm{GR}$, and CAT caused by $\mathrm{Cd}$ was more pronounced in $\mathrm{K}$ sufficient leaves than in K-deficient leaves (Figure 5A-D). AsA and GSH are important antioxidants in plants (Gill and Tuteja, 2010; Cuypers et al., 2010). It was observed that the decrease in ASA and GSH contents caused by $\mathrm{CdCl}_{2}$ was greater in $\mathrm{K}$-sufficient leaves than in $\mathrm{K}$ deficient leaves. The results of this study also demonstrated that $\mathrm{Cd}$ treatment resulted in a significant decrease in the AsA/DHA and GSH/GSSG ratios in K-sufficient leaves (Figure 6B, D). However, the AsA/DHA and GSH/GSSG ratios in $-\mathrm{K}$ leaves were not affected by $\mathrm{CdCl}_{2}$ (Figure 6B, D).

\section{Effect of $\mathrm{K}$ deficiency on paraquat-induced chlorophyll loss}

Irrespective of the $\mathrm{K}$ supply, floating detached leaves in $10 \mu \mathrm{M}$ PQ solution caused a decrease in chlorophyll content (Figure 7). The decrease in chlorophyll content 


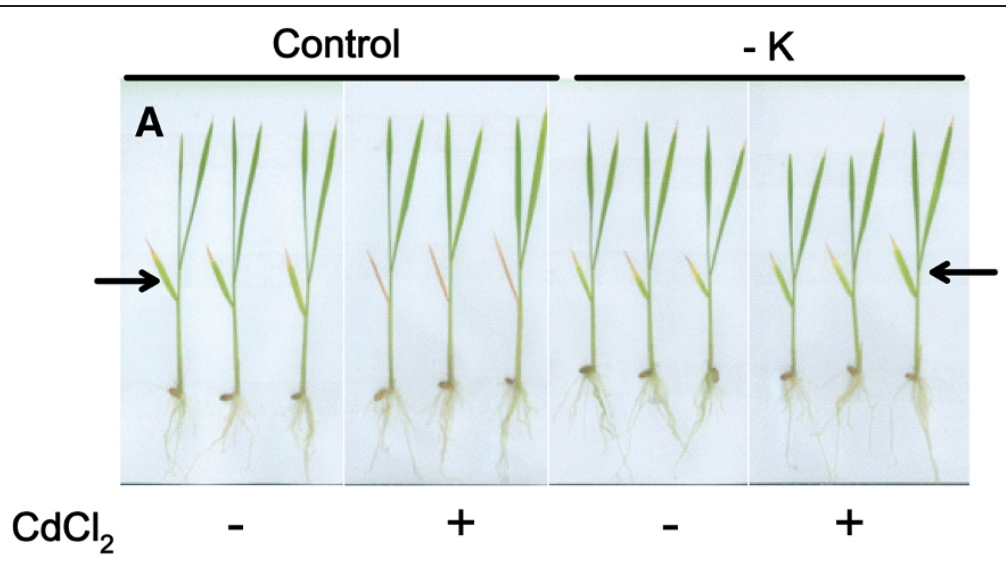

( $5 \mu \mathrm{M}, 6 \mathrm{~d}$ )
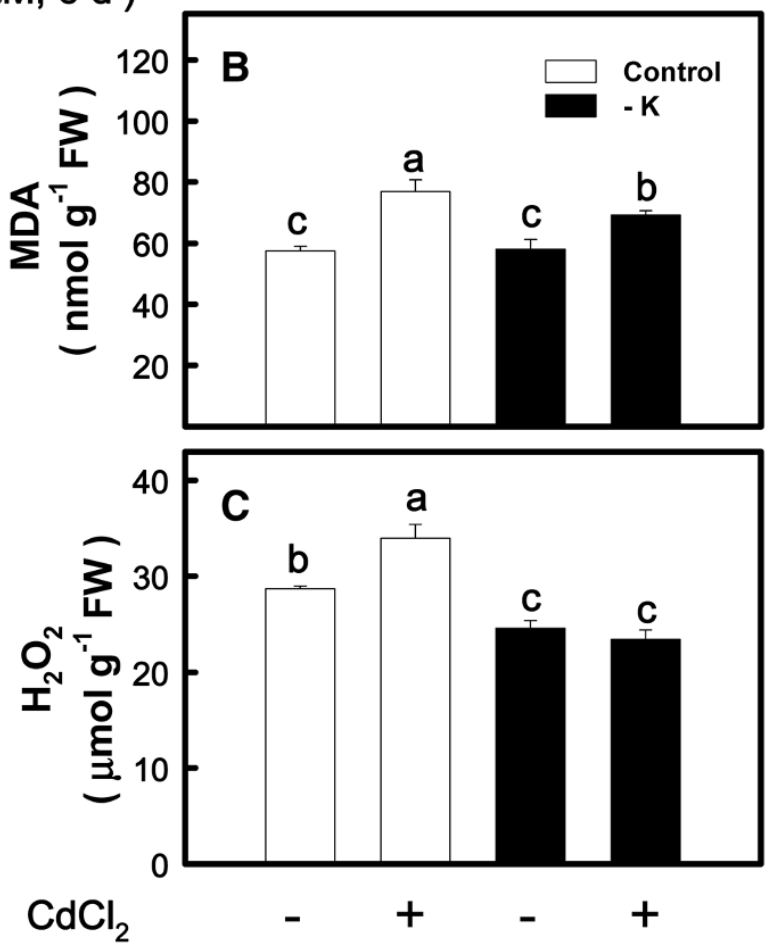

$(5 \mu \mathrm{M}, 6 \mathrm{~d})$

Figure 4 Effect of $\mathrm{CdCl}_{2}$ on the chlorosis (A) and the contents of malondialdehyde (MDA) (B), and $\mathrm{H}_{2} \mathrm{O}_{2}(C)$ in the second leaves of rice seedlings grown under $\mathrm{K}$-sufficient (control) and -deficient $(-\mathrm{K})$ conditions. Rice seedlings were grown under control and $-\mathrm{K}$ conditions for 12 days. Control and $-\mathrm{K}$ seedlings were then transferred to the control and $-\mathrm{K}$ nutrient solution with or without $5 \mu \mathrm{M} \mathrm{CdCl}$ for 6 days, respectively. The second leaves were then used to determine the chlorosis and contents of MDA and $\mathrm{H}_{2} \mathrm{O}_{2}$. Arrows indicate the second leaves. Bars indicate standard errors $(n=4)$. Values with the same letter are not significantly different at $P<0.05$.

by PQ became more evident in K-sufficient compared with K-deficient leaves (Figure 7).

\section{Effect of $\mathrm{K}$ deficiency on the concentration of $\mathrm{Cd}$}

To test if $\mathrm{K}$ deficiency would affect the uptake of $\mathrm{Cd}$, 12-day-old control and K-deficient seedlings were transferred to K-sufficient and -deficient nutrient solutions with or without $5 \mu \mathrm{M} \mathrm{CdCl}_{2}$ for 6 days, respectively. Contrary to our expectation, It was observed that shoots and roots of K-deficient seedlings had higher Cd concentration than those of K-sufficient seedlings (Figure 8A, B). Irrespective of the $\mathrm{K}$ supply, $\mathrm{Cd}$ concentration in roots (Figure $8 \mathrm{~B}$ ) was significantly higher than that in shoots (Figure 8A).

\section{Discussion}

In the present study, rice seedlings were grown under K-sufficient and -deficient conditions for 12 days, by 

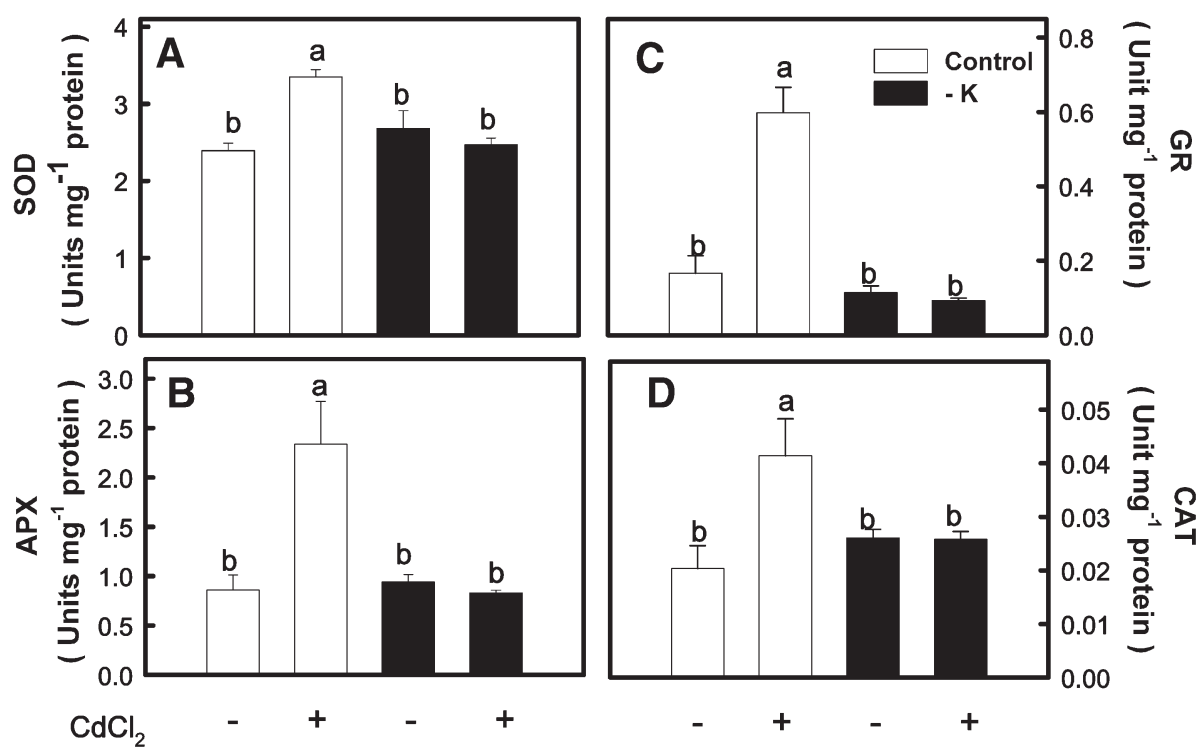

( $5 \mu \mathrm{M}, 6 \mathrm{~d})$

Figure 5 Effect of $\mathrm{CdCl}_{2}$ on the activities of SOD (A), APX (B), GR (C) and CAT (D) in the second leaves of rice seedlings grown under $\mathrm{K}$-sufficient (control) and -deficient $(-\mathrm{K})$ conditions. Rice seedlings were grown under control and $-\mathrm{K}$ conditions for 12 days. Control and $-\mathrm{K}$ seedlings were then transferred to the control and $-\mathrm{K}$ nutrient solution with or without $5 \mu \mathrm{M} \mathrm{CdCl}_{2}$ for 6 days, respectively. The second leaves were then used to determine enzyme activities. Bars indicate standard errors $(n=4)$. Values with the same letter are not significantly different at $P<0.05$.

which time the third leaves of both K-sufficient and deficient rice seedlings were fully grown. K deficiency significantly decreased $\mathrm{K}$ concentrations in shoots and roots of rice seedlings (Figure 1C, F). However, neither DW nor FW in shoots and roots was affected by $\mathrm{K}$ deficiency (Figure 1A, B, D, E). These results suggest that plant biomass is not effective for diagnosis of $\mathrm{K}$ deficiency in the early stage. It appears that $\mathrm{K}$ analysis rather than plant biomass is the most accurate tool to diagnose $\mathrm{K}$ deficiency.
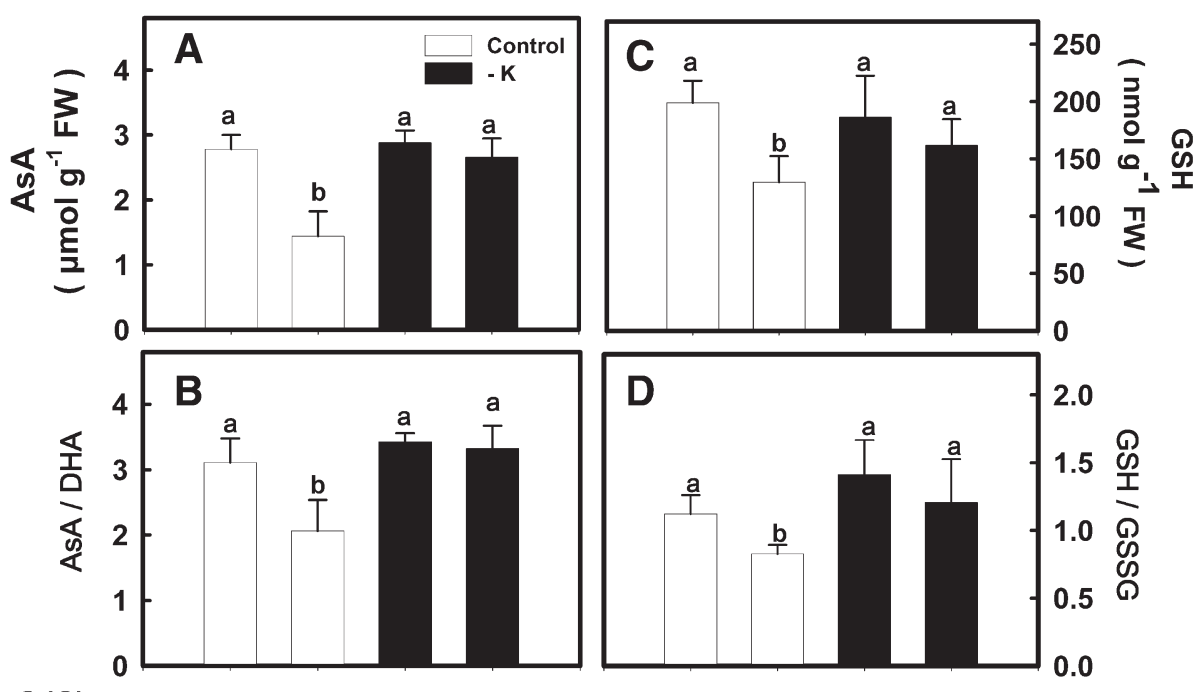

$\mathrm{CdCl}_{2}$

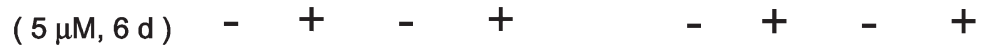

Figure 6 Effect of $\mathrm{CdCl}_{2}$ on the contents of AsA (A) and GSH (C) and the ratios of AsA/DHA (B) and GSH/GSSG (D) in the second leaves of rice seedlings grown under $\mathrm{K}$-sufficient (control) and -deficient $(-\mathrm{K})$ conditions. Rice seedlings were grown under control and - $\mathrm{K}$ conditions for 12 days. Control and $-\mathrm{K}$ seedlings were then transferred to the control and $-\mathrm{K}$ nutrient solution with or without $5 \mu \mathrm{M} \mathrm{CdCl}$ for 6 days, respectively. The second leaves were then used to determine the contents of AsA, DHA, GSH, and GSSG. Bars indicates standard errors $(n=4)$. Values with the same letter are not significantly different at $P<0.05$. 


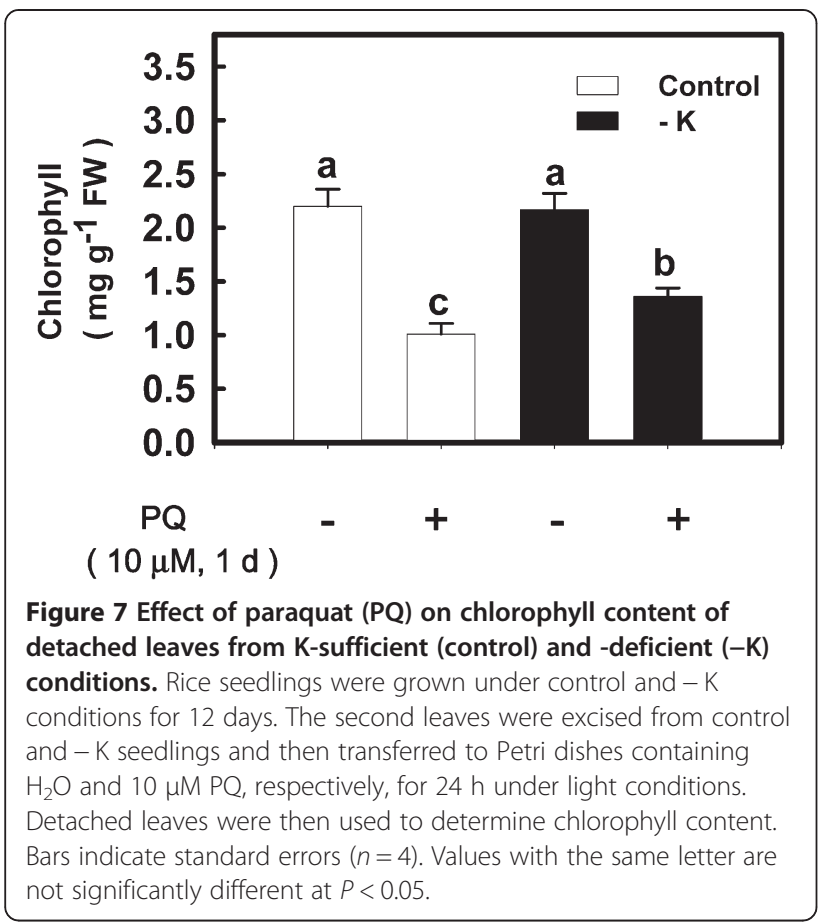

In this study, $\mathrm{Na}$ salt substituted for $\mathrm{K}$ salt under $\mathrm{K}$-deficient conditions. Elimination of $\mathrm{K}$ in this study by $\mathrm{Na}$ gives not only elimination of $\mathrm{K}$ but also leads to increase in $\mathrm{Na}$ concentration. It has been shown that $\mathrm{NaCl}$ inhibited growth of rice seedlings (Lin and Kao, 1995). Since growth of rice seedlings was not affected by $\mathrm{K}$ deficiency (Figure 1A, B, D, E), thus, Na taken up by rice seedlings does not seem to raise the concentration of the $\mathrm{Na}$ in the tissue to the levels that are toxic to rice growth under $\mathrm{K}$ deficiency conditions.

In the present study, $\mathrm{Cd}$ toxicity was evaluated by the decrease in biomass production, chlorosis, and induction of oxidative stress. On the basis of these criteria, it was demonstrated that $\mathrm{K}$ deficiency protected rice seedlings from the toxicity caused by $5 \mu \mathrm{M} \mathrm{CdCl}_{2}$ (Figures 3-6). PQ is an herbicide widely used in agriculture and a well known ROS-generating chemical. Treatment of detached rice leaves with $10 \mu \mathrm{M}$ PQ for $24 \mathrm{~h}$ in the light caused marked chlorophyll loss. This chlorophyll destruction caused by PQ was higher in K-sufficient than K-deficient leaves (Figure 7). Clearly, $\mathrm{K}$ deficiency is able to protect rice seedlings from $\mathrm{ROS}$ damage caused by $\mathrm{Cd}$ or $\mathrm{PQ}$. Thus, the $\mathrm{K}$ nutritional status of plants should be taken into consideration not only in evaluation of Cd toxicity but also in screening studies for PQ resistance. It is well known that $\mathrm{PQ}$ resistant plants also posses a higher resistance to $\mathrm{O}_{3}$ and $\mathrm{SO}_{2}$ (Shaalitiel et al., 1988; Tanaka et al., 1988). Based on the data shown in this study, it might be assumed that K-deficient leaf tissues are also more resistant to other ROS activating stress factors such as $\mathrm{O}_{3}$ and $\mathrm{SO}_{2}$.

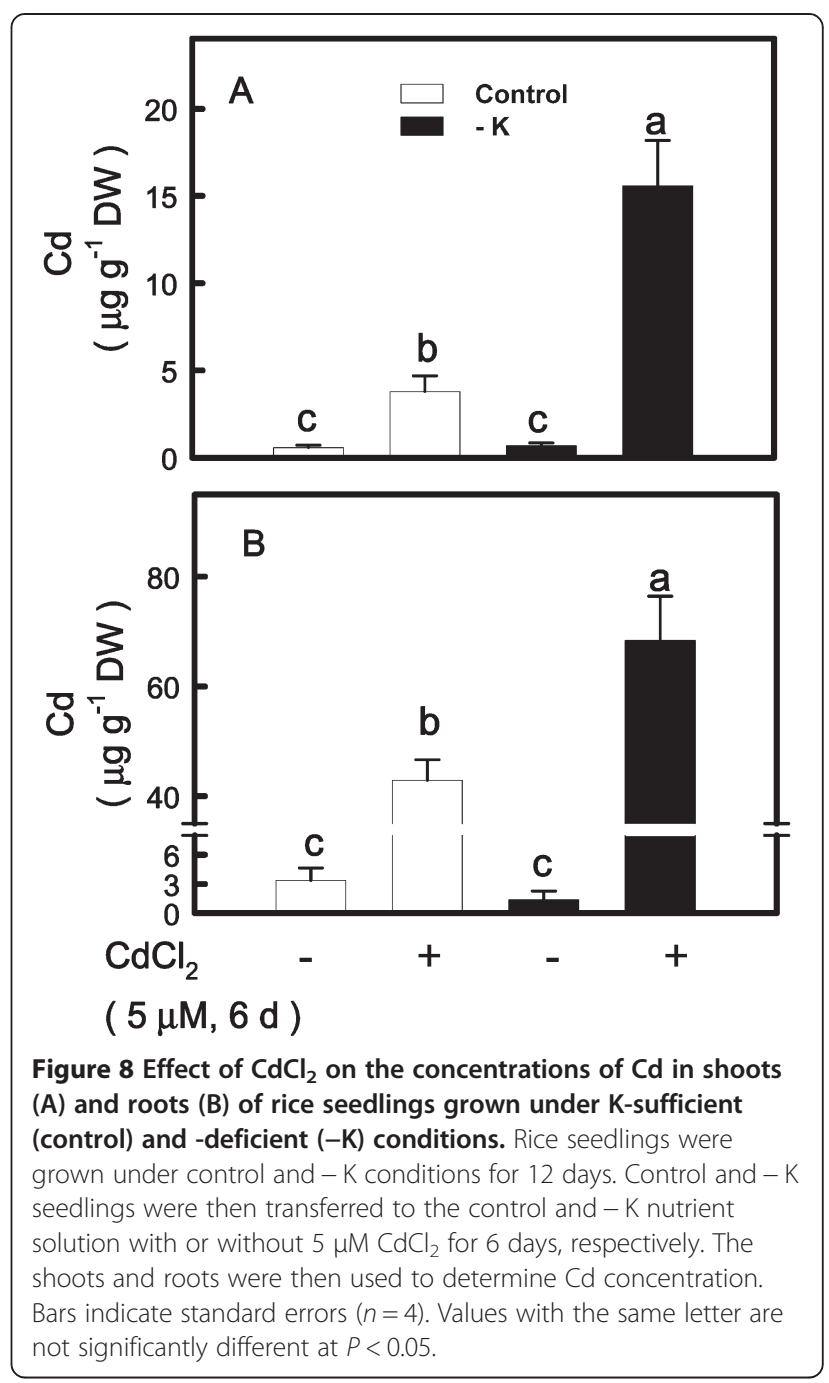

It has been established that the increase in the activities of antioxidant enzymes and /or the contents of antioxidants is important for the improvement of stress tolerance (Gill and Tuteja, 2010). Cho and Seo (2005) demonstrated that seedlings of Cd-resistant Arabidopsis had higher activities of SOD, APX and GR and experienced lower oxidative stress from $\mathrm{Cd}$ exposure. The results of this study show that K-deficient rice leaves have higher activities of antioxidant enzymes, SOD, APX, GR, and CAT than K-sufficient leaves (Figure 2A-D). Enhanced activities of antioxidant enzymes have also been described in K-deficient bean leaves (Cakmak, 1994) and rice plants (Ding et al., 2008).

Irrespective of $\mathrm{K}$ supply, Cd treatment resulted in an increase in $\mathrm{Cd}$ concentration in rice roots and shoots (Figure 8A, B). The $\mathrm{Cd}$ concentration was lower in shoots than in roots (Figure $8 \mathrm{~A}, \mathrm{~B}$ ), indicating that a higher proportion of the $\mathrm{Cd}$ taken up by rice remained in the roots. This is in agreement with previous reports (Jalil et al., 1994; Wu and Zhang, 2002; Ueno et al., 2010). 
Figure 8 showed that $\mathrm{Cd}$ concentration was higher in K-deficient shoots and roots than their respective control shoots and roots. Thus, the protective effect of $\mathrm{K}$ deficiency against $\mathrm{Cd}$ toxicity is mainly due to enhanced antioxidant status but not inhibition of $\mathrm{Cd}$ uptake. It appears that $\mathrm{K}$-deficient leaves experienced lower oxidative stress. In this study, the total shoot and root $\mathrm{Cd}$ concentrations were measured. It is not known whether $\mathrm{K}$ deficiency alters $\mathrm{Cd}$ distribution between vacuolar compartment and the rest of the cell. In future studies, it will be important to determine the effect of $\mathrm{K}$ deficiency on $\mathrm{Cd}$ concentration in different cellular compartments.

\section{Conclusion}

In conclusion, our results indicated that $\mathrm{K}$ deficiency protects rice seedlings from $\mathrm{Cd}$ toxicity. This protective effect of $\mathrm{K}$ deficiency is mainly due to enhanced antioxidant enzyme activities but not inhibition of $\mathrm{Cd}$ uptake.

\section{Abbreviation \\ APX: Ascorbate peroxidase; AsA: Ascorbic acid; CAT: Catalase: DHA: Dehydroascorbate; DW: Dry weight; FW: Fresh weight; GR: Glutathione reductase; GSH: Reduced glutathione; GSSG: Oxidizdd glutathione; PQ: Paraquat; ROS: Reactive oxygen species; MDA: Malondialdehyde; SOD: Superoxide dismutase.}

\section{Acknowledgements}

This work was supported financially by the National Science Council of the Republic of China (NSC 99-2628-B-002-001).

Received: 29 May 2013 Accepted: 29 May 2013

Published: 18 July 2013

\section{References}

Agrawal L, Chakraborty S, Jaiswal DK, Gupta S, Datta A, Chakraborty N (2008) Comparative proteomics of tuber induction, development and maturation reveal the complexity of tuberization process in potato (Solanum tuberosum L.). J. Proteome Res 7:3803-381

Amtmann A, Hammond JP, Armengaud P, White PJ (2006) Nutrient sensing and signaling in plants: Potassium and phosphorus. Adv Bot Res 43:210-257

Amudha J, Balasubnramani G (2011) Recent molecular advances to combat abiotic stress tolerance in crop plants. Biotechnol Mol Biol Rev 16:31-58

Bennicelli RP, Stepniewski W, Zakrzhevsky DA, Balakhnina TI, Stepniewska Z, Lipiec J (1998) The effect of soil aeration on superoxide dismutase activity, malondialdehyde level, pigment content and stomatal diffusive resistance in maize seedlings. Environ Exp Bot 39:203-211

Bradford MM (1976) A rapid and sensitive method for the quantitation of microgram quantities of protein utilizing the principles of protein-dye binding. Anal Biochem 72:248-254

Cakmak I (1994) Activity of ascorbate-dependent $\mathrm{H}_{2} \mathrm{O}_{2}$-scavenging leaves, but not in phosphorus-deficient leaves. J Exp Bot 45:1259-1266

Cakmak I (2005) The role of potassium in alleviating detrimental effects of abiotic stress in plants. J Plant Nutr Soil Sci 168:521-530

Cakmak I (2010) Potassium for better crop production and quality. Plant Soil 335:1-2

Chen SL, Kao CH (1995) Cd induced changes in proline level and peroxidase activity in roots of rice seedlings. Plant Growth Regul 17:67-71

Cho H-H, Seo N-H (2005) Oxidative stress in Arabidopsis thaliana exposed to cadmium is due to hydrogen peroxide accumulation. Plant Sci 168:113-120

Chou T-S, Chao Y-Y, Huang W-D, Hong C-Y, Kao CH (2011) Effect of magnesium deficiency on antioxidant status and cadmium toxicity in rice seedlings. J Plant Physiol 168:1021-1030
Cuypers A, Plusquin M, Remans T, Jozefczak M, Keunen E, Gielen H, Opdenakker K, Nair AR, Munters E, Artois TJ, Nawrot T, Angronsveld VJ, Smeets K (2010) Cadmium stress: an oxidative challenge. Biometals 23:927-940

Das P, Sammantaray S, Rout GR (1997) Studies on cadmium toxicity: a review. Environ Pollut 98:29-36

Dey SK, Kar M (1995) Antioxidant efficiency during callus initiation from mature rice embryo. Plant Cell Physiol 36:543-549

Ding Y-C, Chang C-R, Luo W, Wu Y-S, Ren X-L, Wang P, Xu G-H (2008) High potassium aggravates the oxidative stress induced by magnesium deficiency in rice leaves. Pedosphere 18:316-327

Foster JG, Hess JL (1980) Responses of superoxide dismutase and glutathione reductase activities in cotton leaf tissue exposed to an atmosphere enriched in oxygen. Plant Physiol 166:482-487

Foyer $\mathrm{CH}$, Noctor G (2011) Ascorbate and glutathione: the heart of the redox hub. Plant Physiol 155:2-18

Gill SS, Tuteja N (2010) Reactive oxygen species and antioxidant machinery in abiotic stress tolerance in crop plants. Plant Physiol Biochem 48:909-930

Goggin DE, Colmer TD (2005) Intermittent anoxia induces oxidative stress in wheat seminal roots: assessment of antioxidant defence system, lipid peroxidation and tissue solutes. Funct Plant Biol 32:495-506

Gratăo PL, Polle A, Lea PJ, Azevedo RA (2005) Making the life of heavy metalstressed plants a little easier. Funct Plant Biol 32:481-494

Heath RL, Packer L (1968) Photoperoxidation in isolated chloroplasts. I. Kinetics and stoichiometry of fatty acid peroxidation. Arch Biochem Biophy 125:189-198

Hsu YT, Kao CH (2005) Abscisic acid accumulation and cadmium tolerance in rice seedlings. Physiol Plant 124:71-80

Hsu YT, Kao CH (2007) Toxicity in leaves of rice exposed to cadmium is due to hydrogen peroxide accumulation. Plant Soil 298:231-241

Jalil A, Selles F, Clarke IM (1994) Effect of cadmium on growth and the uptake of cadmium and other elements by durum wheat. J Plant Nutr 17:1839-1858

Kato M, Shimizu S (1987) Chlorophyll metabolism in higher plants, VII. Chlorophyll degradation in senescing tobacco leaves: phenolic-dependent peroxidative degradation. Can J Bot 65:729-735

Kimura J (1931) Response of rice plants to mineral nutrients in a culture solution in comparison with those of barley and wheat. J Imper Agri Exp Sta 1:375-402

Kuo MC, Kao CH (2004) Antioxidant enzyme activities are upregulated in response to cadmium in sensitive, but not in tolerant, rice (Oryza sativa L.) seedlings. Bot Bull Acad Sin 45:291-299

Law MY, Stephen Y, Charles A, Halliwell B (1983) Glutathione and ascorbic acid in spinach (Spinacia oleracea) chloroplasts, The effect of hydrogen peroxide and paraquat. Biochem J 210:899-903

Lin CC, Kao CH (1995) NaCl stress in rice seedlings: the influence of calcium on root growth. Bot Bull Acad Sin 36:41-45

Lin Y-L, Chao Y-Y, Huang W-D, Kao CH (2011) Effect of nitrogen deficiency on antioxidant status and Cd toxicity in rice seedlings. Plant Growth Regul 64:263-273

Marschner H (1995) Mineral Nutrition of Higher Plants. Academic, San Diego

Mengel H, Viro M (1974) Effect of potassium supply on the transport of photosynthates to the fruits of tomatoes (Lycopersicon esculentum). Physiol Plant 30:295-300

Mittler R (2006) Abiotic stress, the field environment and stress combination. Trends Plant Sci 11:15-19

Nakano Y, Asada K (1981) Hydrogen peroxide is scavenged by ascorbate-specific peroxidase in spinach chloroplasts. Plant Cell Physiol 22:867-880

Noctor G, Foyer CH (1998) Ascorbate and glutathione: keeping active oxygen under control. Annu Rev Plant Physiol Plant Mol Biol 49:249-279

Pan J, Plant JA, Voulvoulis N, Oates CJ, Ihlenfeld C (2010) Cadmium levels in Europe: implications for human health. Environ Geochem Health 32:1-12

Paoletti F, Aldinucci D, Mocali A, Capparini A (1986) A sensitive spectrophotometric method for the determination of superoxide dismutase activity in tissue extracts. Anal Biochem 154:536-541

Peoples TT, Koch DW (1979) Role of potassium in carbon dioxide assimilation in Medicago sativa L. Plant Physiol 63:878-881

Piacentini MP, Fraternale D, Piatti E, Ricci D, Vetrano F, Dacha M, Accorsi A (2001) Senescence delay and change of antioxidant enzyme levels in Cucumis sativus L. etiolated seedlings by ELF magnetic fields. Plant Sci 161:45-53

Sanitá di Toppi L, Gabbrielli R (1999) Response to cadmium in higher plants. Environ Exp Bot 41:105-130

Shaalitiel Y, Glazer A, Bocion PF, Gressel J (1988) Cross tolerance to herbidical and environmental oxidant of plant biotype tolerant to paraquat, sulfur dioxide, and ozone. Pestic Biochem Physiol 31:13-23 
Smith IK (1985) Stimulation of glutathione synthesis in photorespiring plants by catalase inhibitors. Plant Physiol 79:104-107

Tanaka K, Furusawa I, Kondo N, Tanaka K (1988) SO 2 tolerance of tobacco plants regenerated from paraquat-tolerant callus. Plant Cell Physiol 29:743-746

Tsai Y-C, Hong C-Y, Liu L-F, Kao CH (2004) Relative importance of $\mathrm{Na}^{+}$and $\mathrm{Cl}^{-}$in $\mathrm{NaCl}$-induced antioxidant systems in roots or rice seedlings. Physiol Plant 122:86-94

Ueno D, Yamaji N, Kono I, Huang CF, Ando T, Yano M, Ma JF (2010) Gene limiting cadmium accumulation in rice. Proc Natl Acad Sci USA 107:1650-1655

Weng X-Y, Zheng C-J, Xu H-X, Sun J-Y (2007) Characteristics of photosynthesis and functions of the water-water cycle in rice (Oryza sativa) leaves in response to potassium deficiency. Physiol Plant 131:614-621

Wintermans JFGM, De Mots A (1965) Spectrophotometric characteristics of chlorophyll $\mathrm{a}$ and $\mathrm{b}$ and their pheophytins in ethanol. Biochim Biophys Acta 109:448-453

Wu FB, Zhang G-P (2002) Genotypic differences in effect of Cd on growth and mineral concentrations in barley seedlings. Bull Environ Contam Toxicol 69:219-227

Zhao DL, Bednarz DM, Oosterhuis CW (2001) Influence of potassium deficiency on photosynthesis, chlorophyll content and chloroplast ultrastructure of cotton plants. Photosynthetica 39:103-109

doi:10.1186/1999-3110-54-2

Cite this article as: Liu et al: Effect of potassium deficiency on

antioxidant status and cadmium toxicity in rice seedlings. Botanical

Studies 2013 54:2.

\section{Submit your manuscript to a SpringerOpen ${ }^{\circ}$ journal and benefit from:}

- Convenient online submission

- Rigorous peer review

- Immediate publication on acceptance

- Open access: articles freely available online

- High visibility within the field

- Retaining the copyright to your article

Submit your next manuscript at $\gg$ springeropen.com 